\title{
Prevention and Management of COVID-19 with Unani Medicine -A Review
}

\author{
M. U. Z. N. Farzana ${ }^{1 *}$, Arshiya Sultana ${ }^{2}$ \\ ${ }^{1}$ Professor, Department of Unani Gynecology and Obstetrics, IIM, University of Colombo, Rajagiriya, Sri Lanka \\ ${ }^{2}$ Associate Professor, Department of Ilmul Qabalat wa Amraze Niswan, National Institute of Indigenous Medicine, Bengaluru, India
}

DOI: $10.36348 /$ sijtcm.2021.v04i01.001

| Received: 07.12.2020 | Accepted: 18.12.2020 | Published: 14.01 .2021

*Corresponding author: M. U. Z. N. Farzana

\section{Abstract}

The world is observing a very strange time fighting an invisible enemy; the novel Coronavirus disease 2019 (COVID19). It is a declared global pandemic now. Initially it was observed in the Wuhan province of China, now fastly spreading around the world. The disease has spread globally with more than 8 million confirmed cases and 439,487 deaths as of June $17^{\text {th }}, 2020$. Human Coronavirus $(\mathrm{HCoV})$ infection causes respiratory diseases with mild to severe outcomes. In the last 15 years, we have witnessed the emergence of two zoonotic, highly pathogenic HCoVs: Severe Acute Rspiratory Syndrome Coronavirus (SARS-CoV) and Middle East Respiratory Syndrome Coronavirus (MERS-CoV). The most common symptoms of COVID-19 are fever, tiredness and dry cough. Some patients may have aches and pains, nasal congestion, runny nose, sore throat or diarrhoea and in case of serious illness develop difficulty in breathing. Research is underway to develop effective vaccines and medicines for the disease. But up to now no any effective management had not been declared. In such conditions, we present the measures described in Unani system of medicine for health protection during epidemics. Unani medicine is a traditional system of medicine developed during the middle ages, which employs natural drugs of herbal, animal and mineral origin for treatment. Traditional systems of medicine are being explored for providing preventive, supportive and rehabilitative care to patients in epidemic/pandemic but no direct evidence is available, some uncontrolled studies on traditional medicines suggest that they may have a direct efficacy on the virus. Unani Physicians emphasized in their classical Unani books under the chapter of influenza about pandemic (Nazla Wabai/ Nazla Haar) and epidemic diseases. The objective of this paper is to discuss in detail the Unani concept, management, treatment of epidemics in general and possible management of current Pandemics of COVID-19, its analysis in the light of ancient books in present scenario.

Keywords: Coronavirus; Pandemic; Nazla Wabai; Nazla Haar; Unani concept.

Copyright $\odot 2021$ The Author(s): This is an open-access article distributed under the terms of the Creative Commons Attribution 4.0 International License (CC BY-NC 4.0) which permits unrestricted use, distribution, and reproduction in any medium for non-commercial use provided the original author and source are credited.

\section{INTRODUCTION}

A novel coronavirus (Fig-1), designated as 2019-nCoV, emerged in Wuhan, China and detected on December 12, 2020 [2]. It is named as Severe Acute Respiratory Syndrome Coronavirus 2 (SARSCoV-2) [3, 4]. Chinese authorities announced on January 7, 2020 that a new type of Coronavirus (novel Coronavirus, $\mathrm{nCoV}$ ) was isolated. This virus was named as Novel
Coronavirus by WHO on January 12 and COVID-19 on 11 February 2020 [5]. This eventually precipitated into the WHO declaring this viral pneumonia as an outbreak on $30^{\text {th }}$ January 2020. On $11^{\text {th }}$ March 2020, due to the global logarithmic, expansion of the cases the coronavirus disease 2019 (COVID-19) was declared as a pandemic by the WHO [6]. 


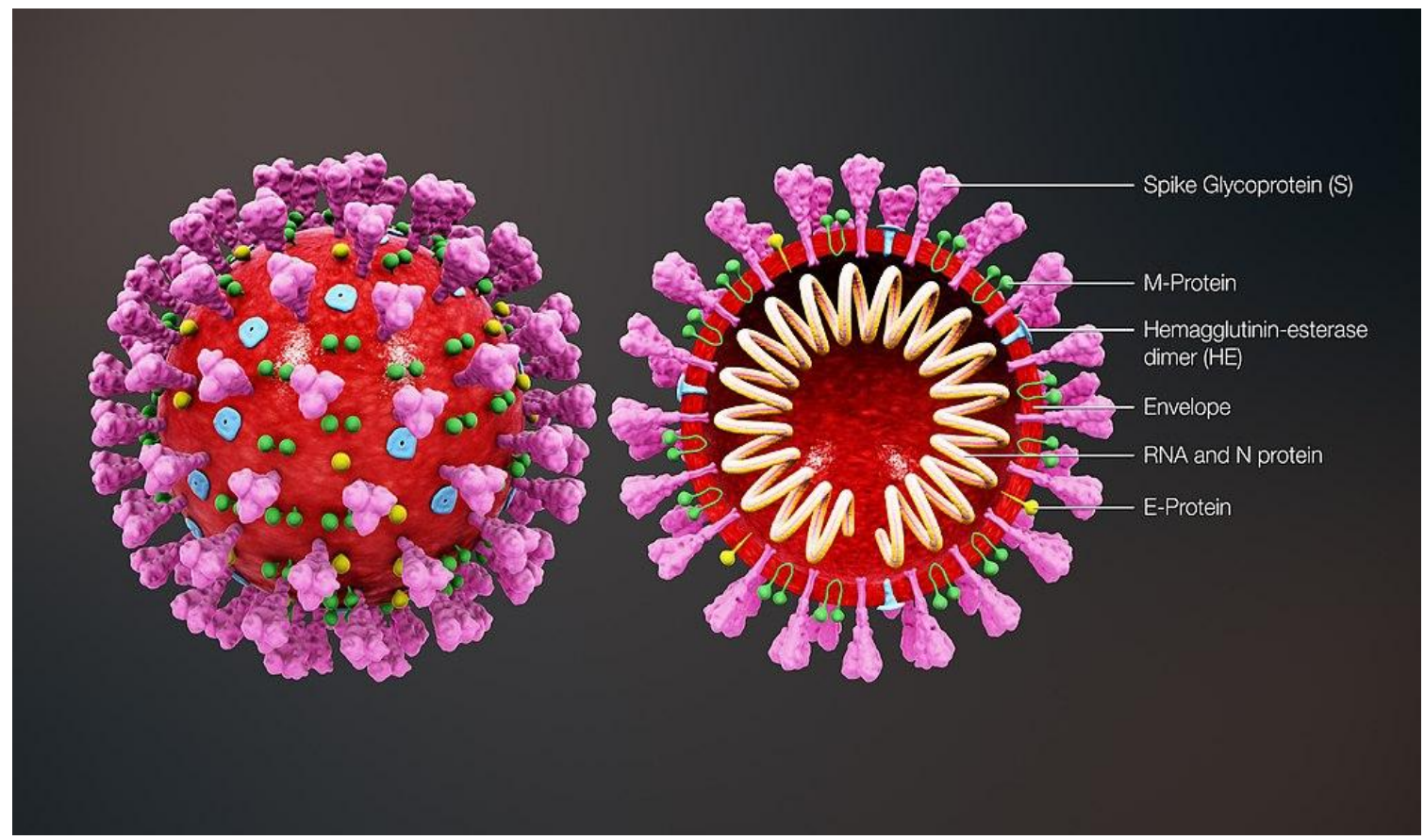

Fig-1: Structure of Coronavirus [1]

The disease has since spread to 190 countries and globally till $17^{\text {th }}$ June 2020 , there have been $8,043,487$ confirmed cases of COVID-19, including 439,487 deaths [7]. Although many details of the emergence of this virus such as its origin and its ability to spread among human to human and details of the origin of this virus is still remain unknown. An increasing number of cases appear to have resulted from human-to-human transmission. Given the Severe Acute Respiratory Syndrome Coronavirus (SARS-CoV) outbreak in 2002 and the Middle East Respiratory Syndrome Coronavirus (MERS-CoV) outbreak in 2012, 2019-nCoV is the third coronavirus to emerge in the human population in the past two decades an emergence that has put global public health institutions on high alert [2].

To explaining the COVID-19 situation of Sri Lanka, the index case was a Chinese tourist who was detected with the illness on $27^{\text {th }}$ of January and admitted to the National Infection Disease Hospital (NIDH). The first Sri Lankan patient known to be a tourist guide who had not traveled overseas was detected to have the illness on the $11^{\text {th }}$ of March. Having understood the potential spread of the disease over the entire population in Sri Lanka. The government of Sri Lanka took immediate sequential measures such as island wide school closure, Travel ban to foreign countries, declaration of special holidays to limit public gathering, shutting down the Colombo International Airport for all arrivals to the island and finally decided to impose island wide lockdown in Sri Lanka [8]. From January $27^{\text {th }}$ to June $17^{\text {th }} 2020$, there have been 1,915 confirmed cases of COVID-19 with 11 deaths and the neighborhood country in India from January $30^{\text {th }}$ to June $17^{\text {th }} 2020$, there have been 354,065 confirmed cases of COVID-19 with 11,903 deaths [7].

Coronaviruses (CoV) belong to the genus Coronavirus in the Coronaviridae. All CoVs are pleomorphic RNA viruses characteristically containing crown-shape peplomers with $80-160 \mathrm{nM}$ in size and 27$32 \mathrm{~kb}$ positive polarity. Recombination rates of CoVs are very high because of constantly developing transcription errors and RNA Dependent RNA Polymerase (RdRP) jumps. With its high mutation rate, Coronaviruses are zoonotic pathogens that are present in humans and various animals (Fig-2) with a wide range of clinical features from asymptomatic course to requirement of hospitalization in the intensive care unit; causing infections in respiratory, gastrointestinal, hepatic and neurologic systems [9-11] . 


\begin{tabular}{|c|c|c|c|}
\hline Virus (Disease) & Origin Virus & Intermediate host & Host \\
\hline $\begin{array}{l}\text { SARS-CoV-1 } \\
\text { (SARS 2002) }\end{array}$ & SARS-like Bat-CoV & Civet Cat & \\
\hline $\begin{array}{l}\text { MERS-CoV } \\
\text { (MERS 2012) }\end{array}$ & SARS-like Bat-CoV & Camel & 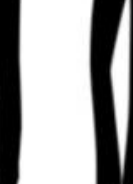 \\
\hline $\begin{array}{l}\text { SARS-CoV-2 } \\
\text { (COVID 2019) }\end{array}$ & BaT-CoV RaTG13 & $\begin{array}{l}\text { Pangolin (could be origin } \\
\text { as well [Pangolin-CoV]) }\end{array}$ & Humans \\
\hline
\end{tabular}

Fig-2: Summary of the natural reservoir, intermediate host and target in major Coronaviruses [6]

At first, an unknown pneumonia case was detected on December 12, 2019, and possible influenza and other coronaviruses were ruled out by laboratory testing.

Despite worldwide efforts to contain it, the pandemic is continuing to spread for want of a clinically-proven prophylaxis and therapeutic strategy [12]. Consequently, it is necessary that scientific community must draw on pluralistic knowledge systems available globally. In the absence of any proven treatment option, many drugs are under investigation to control this disease with a potentially fatal outcome. Chloroquine is one of the widely used drugs, with in vitro evidence that it reduces viral replication [13]. WHO welcomes innovations around the world including repurposing drugs, traditional medicines and developing new therapies in search for potential treatment for COVID-19. WHO is also working with research institutions to select herbal medicine products which can be investigated for clinical efficacy and safety for COVID-19 treatment. Drawing on the original Unani classics, contemporary scientific studies, and our experiential knowledge on similar clinical settings, here we propose a pragmatic plan for interventions. In this context, traditional systems of medicine are being explored for providing preventive, supportive and rehabilitative care to patients. Although no direct evidence is available, some uncontrolled studies on traditional medicines suggest that they may have a direct efficacy on the virus. Unani medicine is one of the officially recognized traditional medicine, which are represented by the acronym AYUSH (Ayurveda, Yoga, Unani, Siddha and Homeopathy). In coherence with the success of TCM (Traditional Chinese Medicine) in managing a communicable pandemic, it is logical and essential to explore how Unani system can help in addressing the COVID-19 challenge [14, 15]. Indeed, this is the time to mainstreaming the AYUSH systems to transform Indian healthcare [16] and demonstrate the potential of AYUSH systems in addressing the challenge and restoring health.

Unani system of medicine has a well description of management and preventive measures drugs that are utilized in many infectious diseases, including respiratory infections. Some of these drugs have been scientifically proved to have specific antiviral [17] and immunomodulatory [18] activity. The objective of this paper is to an overview of Covid-19 and SARS-CoV-2, Unani concept of infectious and epidemic diseases and their preventive measures, and a possible approach to the management of Covid-19 with Unani medicine.

\section{METHODOLOGY}

For present manuscript, Unani classical treatises like Al-Qanun fi'l Tibb (Avicenna's Canon of Medicine), Al Hawi fi'l Tibb (Rhazes's Continen Libers), Jurjani's Dhakhira Khawarizam Shahi, Kamil al-Sana'a al-Tibbiyya, Firdaws al-Hikmat fi'lTibb (RabbanTabari's Paradise of Wisdom), Kitab alMukhtarat Fi'l Tibb, Jamia al-Hikmat, Kitab al-Kulliyat (The Complete Book on Medicine) by Ibn Rushd (1126-1198 CE), Kitab al-Mansoori (Book dedicated to Caliph Mansoor) by Zakariya Raz were explored for information related to epidemic diseases. In addition, For information on SARS-CoV-2 and Covid-19, we searched recent studies on a variety of scientific websites such as Cochrane Database, Google Scholar, Pubmed, Science Direct, Medline and Ovid search engines were explored. The terms such as were 'SARS- 
CoV-2', 'Covid-19', 'history', 'prevalence', 'symptoms', 'transmission' and 'pandemic'.

\section{RESULTS}

\section{Corona Virus Disease 2019}

On the $7^{\text {th }}$ January 2020, the China CDC discovered the virus called novel coronavirus 2019 (2019-nCoV) which was colloquially noted as the "Wuhan Coronavirus". The WHO renamed it to SARSCoV-2 to destigmatize the association of the virus with any geographic location or nationality and relate it to the disease symptomatology. The SARS-CoV-2 virus is genetically similar to the SARS Coronavirus of 2002 (SARS-CoV-1) [5]. SARS-CoV2 is from the beta Coronavirus family, it is a positive-sense, singlestranded RNA, enveloped virus that is $50-200 \mathrm{~nm}$ in diameter [19].

Modes of transmission traced in an imported case are through droplet transmission, fecal-oral route, conjunctiva and fomites [20, 21]. Additionally, local transmission can be traced back to the patient's bodily fluids such as respiratory droplets, saliva, feces, and urine [21].

The symptomatology of COVID-19 was extensively discussed in WHO-China joint report on COVID-19 ( $n=55,924)$ [22]. Patients with COVID-19 present with pyrexia in $85 \%$ of cases during their illness course, but only $45 \%$ are febrile on early presentation [23]. Moreover, cough is seen in $67.7 \%$ of patients and sputum is produced in $33.4 \%$. Respiratory symptoms such as dyspnea, sore throat, and nasal congestion present in $18.6 \%, 13.9 \%$, and $4.8 \%$ of cases, respectively [23]. Constitutional symptoms such as muscle or bone aches, chills, and headache are seen in $14.8 \%, 11.4 \%$ and $13.6 \%$ of the cases, respectively [6]. Gastrointestinal (GI) symptoms such as nausea or vomiting and diarrhea are seen in 5\% and $3.7 \%$ of the cases, respectively. More severe insult on the lung tissue can result in acute respiratory distress syndrome (ARDS) which can further precipitate septic shock. These two complications are the major contributors to intensive care unit (ICU) care and mortality from COVID-19 in patients older than 60 years, with smoking history, and co-morbid medical conditions.

\section{Concept of Epidemics in Unani Medicine and COVID-19}

Corona virus disease (COVID-19) is an infectious disease caused by a newly discovered corona virus and the common signs of COVID- 19 infection are similar to the common cold and include respiratory symptoms such as dry cough, fever, shortness of breath, and breathing difficulties. As per the Unani concept, it has been defined under the heading of an epidemic fever (Humma Wabaiya), the symptoms are similar or resemble that of present nCoV/COVID-19 virus. The first clear and scientific description between small pox and measles was put forth by Al Razi and also Al Razi know about the management about infectious diseases [24]. Al-Razi mentioned fourteen chapters in his book known as Al Judri wal Husba Al Hawi. First chapter is describing the epidemiological triad a recent innovation, though the term is not used as such, in medicine that tells the agent, host and environment relationship and tells infectious disease epidemiology [25]. He was the first medical man who was given the differential diagnostic points to diagnose the two highly and most prevalent infectious diseases in his time such as measles and smallpox [26]. The manuscript comprises 14 chapters, in $12^{\text {th }}$ chapter incorporate dietetic planning of not only for small pox and measles but also for other acute respiratory infectious diseases [27]. $13^{\text {th }}$ chapter consists of the management of smallpox and measles [26]. The another book of $\mathrm{Al}$ Razi name as 'Kitab Al Mansoori', which contain 10 chapters, shortly prescribed the management of small pox and measeles and had absolute idea of quarantine; he stated transportation of public must be stopped during epidemic of plague and also advised the people should not together in crowding places when somebody has leprosy or epidemic fever [28]. The Urdu translation of Kitab al Hawi fil Tib written by Razi was translated by Central Council for Research in Unani Medicine (CCRUM) and it contain 23 volumes and mentioned of several infectious diseases such as meningitis, ear infections, throat infections, chest infections including pulmonary tuberculosis, pneumonia and pleuritis, intestinal infections, urinary tract infections and wounds caused by uofoonat (infections) etc [27].

Another ancient physician Jurjani said in his book Zakhera-e- Khwarizam Shahi that "Lying Face down Is Better for the Lungs. Now in recent study proven that for patients hospitalized with coronavirus disease 2019 (COVID-19) and on ventilators, lying face down was better for the lungs, according to a research letter published in the American Thoracic Society's American Journal of Respiratory and Critical Care Medicine [29].

Another book named as Sharah e Asbab is a translated book of Persian scholar Najeebuddin Samarqandi in $13^{\text {th }}$ century, mentioned about a type of epidemic influenza in his treatise of Al Asbab va Alamat. In Sharah e Asbab the nazla e wabaiya mentioned in the chapter about Nazla-e- Wabaiya, Samarqandi states that it is associated with fever, sneezing, sore throat, nasal irritation and malaise. Specifically, weakness sets in early in the disease. He further states that a patient of nazla-e-wabaiya may also suffer from cough, diarrhea, and delirium. Pleurisy and pneumonia, if present, worsens the prognosis [30]. The theories and observations closely resemble the contemporary knowledge of infections. 


\section{Preventive Measures and Management of Epidemics and Infectious Diseases (COVID-19) in Unani Medicine \\ Preventive Measures}

Unani Medicine lays great emphasis on the prevention of disease and promotion of existing health through principles of six essential factors (Asbab-eSitta Zarooriyah) of life. They are; Hawa,( Pure air). Ma'Kul-o-Mashrub (Healthy Food and Drink). Harakat-o-Sukun Badani (Active Body movement and Repose). Harkat-o-Sukun Nafsani (Peaceful Psychi movement and Repose). Nawm wa Yaqza (Proper Sleep and Wakefulness). Istifragh wa Ihtibas (Needful Evacuation and Retention). It lays great emphasis on the maintenance of a proper ecological balance and on keeping air, water and food free from all possible pollution and pathogens [31].

An eminent Unani physician Jalinoos (Galen 129-200 CE) postulated that certain diseases caused by pollutants tend to be carried by wind and hence, do disseminate faster; these enter human body through respiratory route [32].

According to Zakariyya al Razi (Rhazes 854$925 \mathrm{CE})$, people who remain physically active and exercise regularly have a lesser susceptibility to epidemic diseases [33]. Patients having a weak constitution and those suffering from underlying diseases are said to be more susceptible during epidemics [34].

Razi mentioned the detail about quarantine and he explained transportation of public must be stopped during epidemic of plague and also he advised the people to retrain together in crowding places if anyone has leprosy or epidemic fever [28]. And also in Unani classical books, Kitabul Mansoori, Tarjuma Zakheera e Khwarzam Shahi, Kamil us Sana mentioned the prevention of epidermic diseases by gargling with lemon juice, washing and surroundings with rose or sandal and fumigation with camphor or oodh. They mentioned about social distancing too [14]. It may prevent spreading of COVID 19 from one person to another person through contaminated air.

\section{Surrounding Care}

In Unani system of medicine most of the classical books mentioned about preventive measures of epidemics (viral fevers) by the use of Tiryaq afeni (Antidote) and bukhoor (fumigation) with other antiviral herbal substances, itre (Unani medicinal value scents) like Musk (Moschus moschiferous) Sandal wood (Santalum album ) Rose (Rosa Damascena), and Sirka (Vinegar). Musk can get absorbed through the skin [35-37]. And also, Arq-e-Gulab (Rosa damascena Herrm.) should be applied on the body and sprinkling on curtains etc. If the air smells foul, then fumigation with sandal (Santalum album L.) and camphor is also advisable. Fumigation with herbs like Qust (Saussurea costus (Falc.) Lipsch.), Kundur (Boswellia serrata Roxb. ex Colebr.), Ood (Paeonia emodi Royle.) and Murr (Commiphora myrrha Nees Engl.) is also mentioned by Ibn Rushd [38]. According to Zakariyya Al Razi explained, some aromatic drugs can destroy infectious agents and should be used as fumigants during epidemics. For instance Amber (Liquidambar acalycina H. T. Chang), Loban (Styrax benzoides W. G. Craib), Sandroos (Hymenaea verrucosa Gaertn.) Za'fran (Crocus sativus L.), Aabnoos (Diospyros ebenum J. Koenig ex Retz.), Mastagi (Pistacia lentiscus L.), Mushk (Moschus moschiferus L.), Izkhar (Cymbopogon jwarancusa (Jones) Schult.), Abhal (Juniperus communis L.), Zanjabeel (Zingiber officinale Roscoe), Sibr (Aloe vera L.), Olive gum etc [33].

\section{Ilaj bil Ghiza (Management by Food)}

Unani medicine emphasized that ghiza (food) is important supporting piller of life. Ghiza improves vitality, strength and tabiyat (immunity) during epidemics, it is advised to avoid meat, sweets, and fruits with high water content. If meat has to be taken, then that of birds found on mountains may be preferred over animal meat. Fish should be entirely avoided [38]. These restrictions were placed probably because the zoonotic spread of infections was speculated, and fish and animals living near the ground were more likely to be infected than those living at higher altitudes. It is also advised to consume citrus and sour fruits, especially angoor (grapes), saib (apples), leemoon (lemon), etc.

The fourth chapter of Al-Mansuri discuss about infectious diseases which are more common in rainy season and advised the public to take fruits particularly apple, grapes, pomegranate, barley water and lemon frequently for prevention of infectious diseases [28].

\section{Ilaj bil Dawa (Management by Medicine)}

As per Unani classical wisdom, improving immunity with immune boosters is one of the key approaches for prevention of disease and maintenance of health. Therefore, a strategy to enhance immunity and provide symptomatic relief in upper respiratory tract infection is important.

Unani scholars have prescribed certain drugs that may be used as health protecting drugs during epidemics. They have emphasized more on the use of certain drugs which are known to improve host immunity during the outbreak of epidemics, endemics and pandemics. Single (Table-1) and compound Unani formulations (Table-2) mentioned in Unani classical books, may prove to be beneficial and can be used under the supervision of qualified Unani physicians for possible immune-boosting / symptomatic relief in upper respiratory tract infections. 
Table-1: Dawa (drugs) which can be used as a Bakhoor (fumigation) and disinfectants

\begin{tabular}{|c|c|c|c|}
\hline Unani Tibbi Name & Botanical Name/ English Name & Method of Use & References \\
\hline $\begin{array}{l}\text { Kafoor } \\
\text { Sandalwood }\end{array}$ & $\begin{array}{l}\text { Camphor } \\
\text { Santalum album }\end{array}$ & Room freshener & {$[35,39]$} \\
\hline Arq Gulab & Rose water & use room freshener spray & [28] \\
\hline $\begin{array}{l}\text { Kafoor } \\
\text { Oodh }\end{array}$ & $\begin{array}{l}\text { Camphor } \\
\text { Agar wood }\end{array}$ & fumigation of house & [28] \\
\hline Sikanjabeen & Vinegar & Spray to keep the air clean & [38] \\
\hline $\begin{array}{l}\text { Qust } \\
\text { Kundur } \\
\text { Ood } \\
\text { Murr }\end{array}$ & $\begin{array}{l}\text { Saussurea costus } \\
\text { Boswellia serrata } \\
\text { Paeonia emodi } \\
\text { Commiphora myrrha }\end{array}$ & Use as fumigation & [38] \\
\hline $\begin{array}{l}\text { Amber } \\
\text { Loban } \\
\text { Aabnoos } \\
\text { Mastagi } \\
\text { Izkhar } \\
\text { Sibr }\end{array}$ & $\begin{array}{l}\text { Liquidambar acalycina } \\
\text { Styrax benzoides } \\
\text { Diospyros ebenum } \\
\text { Pistacia lentiscus L } \\
\text { Cymbopogon jwarancusa } \\
\text { Aloe vera }\end{array}$ & For instance & [33] \\
\hline
\end{tabular}

Table-2: Single Drugs which can be used in epidemics mentioned in Unani Classical Texts

\begin{tabular}{|c|c|c|c|c|}
\hline $\begin{array}{l}\text { Unani } \\
\text { Name }\end{array}$ & $\begin{array}{l}\text { Botanical Name/ } \\
\text { English Name }\end{array}$ & Action & Dose & References \\
\hline Behi dana & Cydonia oblonga & $\begin{array}{l}\text { Antioxidant, } \\
\text { immunomodulator, antiallergic and anti- } \\
\text { influenza }\end{array}$ & $3-5 \mathrm{gm}$ & {$[40,41]$} \\
\hline Unnab & Zizyphus jujuba & $\begin{array}{l}\text { Anti-influenza, immunomodulator, } \\
\text { antioxidant }\end{array}$ & $5 \mathrm{pcs}$ & [41] \\
\hline Sapistan & Cordia myxa & $\begin{array}{l}\text { Immunomodulator, tracheal smooth muscle } \\
\text { relaxant, anti-oxidant }\end{array}$ & $9 \mathrm{pcs}$ & {$[42-45]$} \\
\hline Karanjwa & Caesalpinia bonducella & $\begin{array}{l}\text { Antipyretic, antimicrobial, anti- } \\
\text { inflammatory, immunomodulator }\end{array}$ & 3 to $5 \mathrm{gm}$ & {$[46,47]$} \\
\hline Imli & Tamarindus indica $\mathrm{L}$ & Analgesic, anti-inflammatory & & {$[38,48]$} \\
\hline Halela & Terminalia chebula Retz & Anti-bacterial & & {$[38,49]$} \\
\hline Amaltas & Cassia fistula $\mathrm{L}$ & Immunomodulatory, antioxidant & & {$[38,50]$} \\
\hline $\begin{array}{l}\text { Tukhm-e- } \\
\text { Kasoos }\end{array}$ & Cuscuta reflexa & Anti viral & $15 \mathrm{gm}$ & {$[51]$} \\
\hline Turanjabeen & Alhagi pseudalhagi & Anti-microbial, anti-oxidant, & & [38] \\
\hline Kalonji & Nigella sativa & Anti viral & $1-2 \mathrm{gm}$ & [52] \\
\hline Aslassus & Glycyrrhiza glabra & Anti viral & $5-10 \mathrm{gm}$ & [53] \\
\hline Khayar shamber & Cassia fistula & Anti viral & $10-20 \mathrm{gm}$ & [53] \\
\hline Gilo & Tinospora cordifolia & Anti viral & $5-10 \mathrm{gm}$ & [53] \\
\hline Asgandh & Withania somnifera & immunomodulator & $5 \mathrm{~g}$ & {$[36,54,55]$} \\
\hline
\end{tabular}

Table-3: Compound formulations which can be used in epidemics mentioned in Unani Classical Texts

\begin{tabular}{|l|l|l|l|}
\hline $\begin{array}{l}\text { Compound } \\
\text { formulations }\end{array}$ & Mode to use & Dose & References \\
\hline $\begin{array}{l}\text { Rub-e-toot } \\
\text { Arq-e-gulab -e-jau }\end{array}$ & $\begin{array}{l}\text { Gargling the mouth during respiratory } \\
\text { conditions before sleep }\end{array}$ & As per required & {$[56]$} \\
\hline Khameera Marwareed & taken orally as an immunity enhancer & $3-5 \mathrm{~g}$ & {$[53]$} \\
\hline Roghan e Babuna Sada & $\begin{array}{l}\text { In case of respiratory discomfort, local } \\
\text { application on chest }\end{array}$ & Required amount & {$[58]$} \\
\hline Arq-e-Ajeeb & As a inhalation & $2-5$ drops & {$[53]$} \\
\hline Tiryaq Wabai & & 2.5 gm twice a day & {$[59,60]$} \\
\hline Habb-e-Bukhar & For fever & $\begin{array}{l}250 \mathrm{mg} \text { (pill) twice daily for 6- } \\
12 \text { years of age } \\
500 \mathrm{mg} \text { (pill) twice daily for } \\
\text { above 12 years of age }\end{array}$ & {$[58]$} \\
\hline
\end{tabular}


M. U. Z. N. Farzana \& Arshiya Sultana., Sch Int J Tradit Complement Med, Jan, 2021; 4(1): 1-10

\begin{tabular}{|c|c|c|c|}
\hline Hab e Hindi Zeeqi & For difficulty in breathing & $\begin{array}{l}125-250 \mathrm{mg} \text { ) } \\
125 \mathrm{mg} \text { (pill) twice daily for } 6- \\
12 \text { years of age } \\
250 \mathrm{mg} \text { (pill) twice daily for } \\
\text { above } 12 \text { years of age }\end{array}$ & ayu \\
\hline $\begin{array}{l}\text { Sharbat Zufa } \\
\text { Murrakab }\end{array}$ & For all the symptoms of influenza & $\begin{array}{l}20 \mathrm{ml} \text { with warm water, every } \\
\text { four hours orally }\end{array}$ & {$[60,61]$} \\
\hline $\begin{array}{l}\text { Khamira } \\
\text { Gaozaban }\end{array}$ & For all the symptoms of influenza & $\begin{array}{l}6 \mathrm{~g} \\
30 \mathrm{ml} \\
\text { Twice a day ,Orally }\end{array}$ & {$[61]$} \\
\hline $\begin{array}{l}\text { Qairooti Arad-e } \\
\text { Karsana }\end{array}$ & For all the symptoms of influenza & $\begin{array}{l}20 \\
\text { gm } \\
\text { Local application apply } \\
\text { Luke warm on the chest } \\
\text { and covered by cotton } \\
\text { or cloth three times a } \\
\text { day }\end{array}$ & [61] \\
\hline
\end{tabular}

\section{Some Nushkha (Prescriptions) for Epidermis/Pandemics}

\section{Nushkha-1}

Sibr (Aloe vera L.) -1part

Murr makki (Commiphora myrrha Nees Engl.)- 1 part

Za'fran (Crocus sativus L.)- 2 parts.

These drugs should be finely powdered and taken in a dose of $2.4 \mathrm{~g}$ per day [38].

\section{Nushkha-2}

Gul-e-surkh- 15 gr

Kishneez khushik -15 gr

Sandal sufaid- $15 \mathrm{gr}$

Tukhm-e- khurfa-7gr

Tabasheer $-7 \mathrm{gr}$

Kaharuba Shamai $-7 \mathrm{gr}$

Busad Ahmar- 7gr

Abreeshum Kham mukashsher- 7 grams

Mushik Khalis -01gr

Nabat safaid- 300gram,

Soak all ingredients in water for full night and boil in the early morning and use filtered extract along with Arq Gowzaban 75ml [62, 63]

\section{Nushkha-3}

Kalonji-2g

Darchini $-2 \mathrm{~g}$

Heel kurd-2g

Zanjabeel khushk-2gr

Unnab-2gr

Boil all in $150 \mathrm{ml}$ water while remain $75 \mathrm{ml}$. use this decoction 2-3 times a day.

\section{Prevention Strategies \\ Self-Protection}

CDC reminds basic measures such as hand washing, using disinfectant solutions, avoiding contact with patients in order to prevent the spread of viruses by droplets $[64,65]$. Avoiding contact with people who are already presenting with symptoms, as well as avoiding gathering or crowded places. Travel to outbreak areas must be prohibited. A healthy individual must maintain at least six feet distance from individuals presenting with symptoms [67]. Taking personal protective measures such as the use of gloves, eye masks and N95 masks during the examination of patients with a suspected history of COVID-19 contact $[66,67]$. High-risk individuals such as those older than 65 or having chronic comorbidities without any symptoms are also required to self-quarantine to decrease the likelihood of COVID-19 contraction [65].

\section{Herd Protection}

On the development of any symptoms, the potential patient should remain quarantined in selfisolation away in a separate room with a separate bathroom for at least 14 days. This self-isolation must be extended to pets as well, as there is a recorded case of a human-to-dog transmission [68]. If there are any further concerns about COVID-19, then immediate contact with the public health hotline or general practice clinic via telemedicine must be established to attain a potential diagnosis. Face masks (N95) are needed for COVID-19 patients to prevent droplet spread [68].

\section{CONCLUSION}

Over the past 50 years the emergence of many different coronaviruses that cause a wide variety of human and veterinary diseases has occurred. The newest of them, SARS-CoV-2, is, fortunately, lesser on virulence than its two recent predecessors, namely SARS-CoV and MERS, but higher in infectivity. This simply implies that it has more chances of reaching the susceptible population and causing higher mortality. The COVID-19 cases mortality are likely to increase drastically. This now placed a huge economic burden in developed and developing countries. The symptoms of Influenza Pandemic (Nazla Wabai/ Nazla Haar) and Epidemic diseases in Unani Medicine and COVID 19 are almost same therefore on the basis of literature all the management and preventive measures described could be adopted in COVID 19 for mild to moderate illness. Concepts of sanitation, isolation, air purification 
and immune-modulation described in Unani medicine remain the basic tenets of infection containment in the contemporary preventive medicine. At present, any confirmed treatments are not available for COVID-19. Therefore now imposing herbal medicines have a significant potential role in reducing the burden in this present era under the AYUSH system, Unani medicine have enough potential and possibility to be employed for prevention and treatment of Amraz e wabaiya (infectious diseases). Numbers of herbo-mineral drugs has been mentioned in the Unani classical which are practiced for various acute infectious diseases since ancient time. The herbo-mineral drugs which mentioned in the Unani classical books are more effective, cost effective, easily available and easy to administer. However, clinical trials need to be conducted on the basis of Unani parameters for generating scientific evidence on safety and efficacy of these drugs in COVID-19 infection for wider acceptance.

\section{REFERENCES}

1. https://www.scientificanimations.com . retrieved on 14.06.2020

2. Shrikrushna S. U. (2020). A Review on Corona Virus (Covid-19) Journal of WJPLS, 6(4), 109115.

3. Zho, P., Yang, X. L., Wang, X. G., Hu, B., Zhang, L., \& Zhang, W. (2020). A pneumonia outbreak associated with a new coronavirus of probable bat origin. Nature, 579:270.

4. Chen, N., Zhou, M., Dong, X., Qu, J., Gong, F., \& Han, Y. (2020). Epidemiological and clinical characteristics of 99 cases of 2019 novel coronavirus pneumonia in Wuhan, China: a descriptive study. Lancet, 395:507.

5. Imperial College London. Report 2: estimating the potential total number of novel coronavirus cases in Wuhan City, China. Jan 2020. https://www.imperial.ac.uk/mrc-

globalinfectiousdisease-analysis/news--wuhancoronavirus

6. Pramath, K., Nagham, K., \& Baig, M. N. (2020). A Comprehensive Literature Review on the Clinical Presentation, and Management of the Pandemic Coronavirus Disease 2019 (COVID-19. Cureus, 12(4), 12-21.

7. https://covid19.who.int/region/searo/country/in retrieved on 14.06.2020

8. http://www.epid.gov.lk/web/index.php?option=co m_content $\&$ view $=$ article $\&$ id $=225 \&$ Itemid $=518 \& 1$ ang=en retrieved on 11.05.2020

9. Woo, P. C., Huang, Y., Lau, S. K., \& Yuen, K. Y. (2010). Coronavirus genomics and bioinformatics analysis. Viruses, 2, 1804-20.

10. Drexler, J. F., Gloza-Rausch, F., Glende, J., Corman, V. M., Muth, D., \& Goettsche, M. (2010). Genomic characterization of severe acute respiratory syndrome-related coronavirus in European bats and classification of coronaviruses based on partial RNA-dependent RNA polymerase gene sequences. J Virol, 84, 11336-49.

11. Yin, Y., \& Wunderink, R. G. (2018). MERS, SARS and other coronaviruses as causes of pneumonia. Respirology, 23,130-7.

12. Xu, B., Gutierrez, B., Mekaru, S., Sewalk, K., Goodwin, L., \& Loskill, A. (2020). Epidemiological data from the covid-19 outbreak, real-time case information. Scientific data, 7, 106.

13. De,ponti G.N, da Silva Naue W, Hervé B.B, Piekala D.M, Glaeser S.S, de Fraga Gomes Martins L Dias A.S, (20217), Perme Intensive Care Unit Mobility Score: analysis of mobility improvement in critical care patients admitted to a university hospital in Brazil. J Crit. Care, 42, 399.

14. Rastogi, S. (2020). Viral epidemics and traditional health care systems: it's time to act honestly, proactively and collectively. Annals Ayurvedic Med, 9:9-11.

15. Patwardhan, B., Chavan-Gautam, P., Gautam, M., Tillu, G., Chopra, A., \& Gairola, S. (2020). Ayurveda rasayana in prophylaxis of covid-19. Curr Sci, 118, 1158-60.

16. Patwardhan, B., \& Tillu, G. (2018). Universal health coverage and AYUSH systems. J Ayurveda Integr Med, 9, 1-2.

17. Cagno, V., Civra, A., Kumar, R., Pradhan, S., Donalisio, M., Sinha, B. N., Ghosh, M., \& Lembo, D. (2015). Ficus religiosa L. bark extracts inhibit human rhinovirus and respiratory syncytial virus infection in vitro. J. Ethno pharmacol, 176, 252257.

18. Nigar, Z., \& Itrat, M. (2013). Evaluation of a Unani polyherbal formulation (Tiryaqe wabai) as an immune stimulator in elderly persons. Anc. Sci. Life, 33, 117.

19. Xu, X., Chen, P., \& Wang, J. (2020), Evolution of the novel coronavirus from the ongoing Wuhan outbreak and modeling of its spike protein for risk of human transmission. Sci China Life Sci, 63:457-460.

20. Xu, 1., Zhang, X., Song, W., Sun, B., Mu, J., Dong, X., \& Wang, B. (2020), Conjunctival polymerase chain reaction-tests of 2019 novel coronavirus in patients in Shenyang, China. Med R xiv. .

21. Ong, S. W. X., Tan, Y. K., \& Chia, P. Y. (2020). Air, surface environmental, and personal protective equipment contamination by severe acute respiratory syndrome coronavirus 2 (SARSCoV-2) from a symptomatic patient. JAMA.12-34.

22. Report of the WHO-China joint mission on coronavirus disease 2019 (COVID-19). (2020). Accessed: $\quad$ March 21, 2020: https://www.who.int/docs/defaultsource/coronaviruse/whochina- joint-mission-oncovid-19-final-report.pdf.

23. Guan, W. J., Ni, Z. Y., Hu, Y. (2020) Clinical characteristics of coronavirus disease 2019 in 
China. N Engl J Med. [Published online ahead of print]:10.1056/NEJMoa2002032

24. Aghamohammadi, A., Moin, M., \& Razaei N. (2010). History of Primary Immuno deficiency Diseases in Iran. Iran J Pediatr. 20(1):16-34.

25. Green, H. W. A. (1847). A treatise on the small pox and measles.Printed for the sydenham society London.

26. Masroor, A. Q. (2020). Covid 19 Pandemic and Unani Medicine: A Review. J Tradit Med Clin Nature, 9, 2.

27. Sherwani, A., Sherwani, A., Azam, A. (2006). AlRazi A. Great Arab Epidemiologist Al-Razi \& His Life Time Achievements. JISHIM, 5, 54-56.

28. Parvez, A,, Zaheer, A,, Noman, A., \& Kabiruddin, A. (2016). Razi's unique approach to Amraz-eWabaiya (Infectious Diseases): An overview. International Journal of Herbal Medicine, 4(6): 176-178.

29. Razi Z. (1991). Kitab al-Mansuri. (Urdu translation by CCRUM), Dept. of AYUSH, Ministry of Health and Family Welfare, Govt. of India: New Delhi.; 10(174-177):424-426.

30. Patient facing downward better for the lungs with Covid-19. (2019), Contagion.

31. Samarqandi, N. (2010). Sharah Asbab. Aijaz Publishing House: New Delhi.

32. https://www.nhp.gov.in/concept-of-prevention-ofdiseases-in-unani-medicine_mtl

33. Parvez, A., Ahmed, Z., Anwar, N., \& Ahmed, K. (2016). Razi's unique approach to Amraz-eWabaiya (Infectious Diseases): An overview. International Journal of Herbal Medicine, 4(6), 176-178.

34. Razi, Z. (2008). Kitab al-Hawi. Central Council for Research in Unani Medicine: New Delhi.

35. Sina, I. (1878). Al Qanoon Fil Tibb. Munshi Nawal Kishore: Lucknow.

36. Majoosi, A. A. Kamilo Sana. Published by munshi naval Kishore: Lucknow, 85.

37. Al-Baytar, Z. (1999., Al Jami li Mufradat al Adviya wal Aghziya. CCRUM; New Delhi.

38. Rushd, I. (1987). Kitab al-Kulliyat, $2^{\text {nd }}$ ed. Central Council for Research in Unani Medicine: New Delhi.

39. Sena, SA. A.E. Al Qanoon, Idara Kitab us Shifa: New Delhi.

40. Al-Snafi, A. E. (2016). The medical importance of Cydonia oblonga-A review. IOSR Journal of Pharmacy, 6(6), 87-99.

41. Hamauzu, Y., Yasui, H., Inno, T., Kume, C., \& Omanyuda, M. (2005). Phenolic profile, antioxidant property, and anti-influenza viral activity of Chinese quince (Pseudocydonia sinensis Schneid.), quince (Cydonia oblonga Mill.), and apple (Malus domestica Mill.) fruits. J Agric Food Chem, 23;53(4):928-34.

42. Hong, E. H., Song, J. H., \& Kang, K. B. (2015). Anti-influenza activity of betulinic acid from on influenza A/PR/8 virus. Biomol Ther, 23(4):345349.

43. Ali, W. R., Al-Asady, Z. T., \& Ibrahim, A. A. (2015). Immunomodulatory of Cordia myxa (L.) aqueous extract fruit in immunized mice with hydatid cyst fluid. Journal of Natural Science Research, 5(10): 75-83.

44. Ad-Dahhan, H. A. A. (2010). Detection of Immunomodulatory activity of alcoholic extract of Cordia myxa (L.) fruit. AL-Qadisyia Journal of Applied Sciences, 15(4): 1-8.

45. Afzal, M., Obuekwe, C., Khan A. R., \& Barakat, H. (2007). Antioxidant activity of Cordiamyxa L. and its hepatoprotective potential. EJEAF Che, 8(6), 2236-2242.

46. Subbiah, V., Nagaraja, P., Narayan, P., \& Nagendra, H. G. R. (2019). Evaluation of Pharmacological Properties of Caesalpinia bonducella Seed and Shell Extract. Pharmacogn J. 11(1):150-154.

47. Archana, P., Tandan, S. K., Chandra, S., \& Lal, J. (2005). Antipyretic and Analgesic Activities of Caesalpinia Bonducella Seed Kernel Extract, Phytother Res, 19(5), 376-8.

48. Komakech, R., Kim, Y. G, Matsabisa, G. M., \& Kang, Y. (2019). Anti-inflammatory and analgesic potential of Tamarindus indica Linn. (Fabaceae): a narrative review. Integr Med Res, 8, 181-186.

49. Saxena, S., Lakshminarayan, N., Gudli, S., \& Kumar, M. (2017). Anti-bacterial efficacy of Terminalia chebula, Terminalia bellirica, Embilica officinalis and Triphala on salivary Streptococcus mutans count - a linear randomized cross over trial, J Clin Diagn Res, 11, ZC47-ZC51.

50. Rahmani, A. H (2015). Cassia fistula Linn: potential candidate in the health management. Pharm. Res, 217-224.

51. Awasthi, L. P. (1981). The purification and nature of an antiviral protein from Cuscuta reflexa plants. Arch Virol, 70(3):215-23.

52. Umar, S., Munir, M. T., Subhan, S., Azam, T., Nisa, Q., Khan, M. I., ... \& Shah, M. A. (2016). Protective and antiviral activities of Nigella sativa against avian influenza (H9N2) in turkeys. Journal of the Saudi Society of Agricultural Sciences.

53. Anonymous. (1975). Kitabul Mutamad fi'l Adwiya al-Mufrada, Daru'l Marifa, Beirut 2013, Essential Drugs List-Unani Medicine, Ministry of AYUSH: New Delhi, 143.

54. Agarwal, R., Diwanay, S., Patki, P., \& Patwardhan, B. (1999). Studies on Immunomodulatory Activity of Withania Somnifera (Ashwagandha) Extracts in Experimental Immune Inflammation. J Ethnopharmacol, 67(1), 27-35.

55. Ziauddin, M., Phansalkar, N., Patki, P., Diwanay, S., \& Patwardhan, B. (1996). Studies on the Immunomodulatory Effects of Ashwagandha, J Ethnopharmacol, 50(2):69-76. 
56. Razi, Z. (1991). Kitab al-Mansoori. Central Council for Research in Unani Medicine: New Delhi.

57. Khan, F., Ali S., Ganie, B. A., \& Rubab, I. (2009). Immuno-potentiating effect of Khamira Marwarid, an herbo-mineral preparation. Methods Find Exp Clin Pharmacol. 31:513-22.

58. Guidelines for Unani practitioners for COVID-19, Government of India, Ministry of AYUSH.

59. Ahmad al-Hasan. (1796). Jurjani. Zakhira Khwar zam Shahi, Vol. 3 (Part-10). Urdu Translation by Hakim Hadi Husain Khan. Munshi Nawal Kishore: Lucknow, 1878.

60. Novel corona virus. WHO. 2019.

61. National formulary of Unani Medicine. (1993), CCRUM, Ministry of Health and Family Welfare, Government of India: New Delhi. 167(224):110215.

62. Kabirudin, H. M. (2009). Hummiyat-e-Qanoon CCRUM: New Delhi.

63. The Unani Pharmacopeia of India. (2007). Department of AYUSH, Ministry of Health and Family Welfare, Government of India: New Delhi, 2007.

64. 2019 Novel Coronavirus. Prevention and Treatment. Available online: https://www.cdc.gov/coronavirus/2019-

ncov/about/ prevention-treatment.html (accessed on 05 June 2020)

65. Updated IPAC recommendations for use of personal protective equipment for care of individuals with suspect or confirmed COVID-19. (2020). Accessed: March 23, 2020: https://www.publichealthontario.ca/-

/media/documents/ncov/updated-ipac-measurescovid-19.pdf?la=en.

66. Chen, Z., Zhang W., \& Lu, Y. (2020). From SARS-CoV to Wuhan 2019- nCoV Outbreak: Similarity of Early Epidemic and Prediction of Future Trends: Cell Press.

67. What to do if you are sick with 2019 Novel Coronavirus. Available online: https://www.cdc.gov/coronavirus/2019-ncov/ about/steps-when-sick.html (accessed on 05 June 2020)

68. Clinical management of severe acute respiratory infection when COVID-19 is suspected: interim guidance. (2020). Accessed: November21, 2020. https://www.who.int/publicationsdetail/clinicalmanagement-of-severe-acute respiratoryinfectionwhen-novel-coronavi. 